Biannual Research Journal Grassroots

Vol.55, No.II, 2021: 22-39

Grassroots

\title{
GENDER EQUALITY, EMPLOYMENT TRENDS AND SUSTAINABLE ECONOMIC GROWTH NEXUS: AN EMPIRICAL EXAMINATION OF LOW-INCOME COUNTRIES
}

\author{
Professor Dr. Uzma Quraishi \\ Vice Chancellor, The Women University Multan \\ Email: uzmaquraishi@yahoo.com \\ Dr. Hina Ali \\ Assistant Professor, Department of Economics, The Women University Multan \\ Email: hinaali@wum.edu.pk \\ Khizra Sardar \\ M.Phil Scholar, Department of Economics, The Women University Multan \\ Email: khizrasardar42@gmail.com
}

\begin{abstract}
This research has been integrated to check the affiliation between gender equality, employment trends, and sustainable economic growth of low income countries. Furthermore, this research validates a classical theory that argued that factoring or adding more variables in a gender specified model will reduce the only portion of residuals but does not rule out the gap. It also considers the impact of gender inequality and employment trends on sustainable economic growth separately and combines. Panel data estimation by using secondary data sources from recognized international organizations such as the United Nations Development Program, World Economic Outlook, and World Economic Situation Perspectives over time. Gender inequality, unemployment, and some other macro-economic, social, demographic, and financial factors are incorporated over 2011 to 2020. This research considers three different statistical models. For statistical estimation of long run affiliation granger causality and Generalized Method of Moment (GMM) is utilized by the researcher. Gender inequality negatively influences sustainable economic growth. Employment trends also contribute to influencing economic growth. Moreover, there is a statistically significant association amid gender inequality, employment trends, and sustainable economic growth. Furthermore, factoring more variables in gender specified models does not rule out gender inequality. There is long term association between gender equality, employment trends, and sustainable economic growth of low income countries. Therefore, when governments or policymakers construct policies about reducing or eliminating gender inequality, they must consider employment trends prevailing in that economy.
\end{abstract}

Keywords: Gender Inequality, Sustainable Economic Growth, Employment Trends, Low Income Countries, Gender Inequality Index, Unemployment, GMM, Granger Causality. 


\section{INTRODUCTION}

Gender-based development assistance could be an influential factor to empower women to participate in labor, land, and goods marketplaces facilitating them to contribute to social, economic, and environmental development to attain sustainable growth (Sever, C., 2018). United Nations (UN) and World Bank (WB) argued that despite focusing on gender neutral strategies by concentrating on women's role in achieving economic development and reducing poverty approaches, leads an economy towards steady economic growth. According to Sever, C. (2018), if females were in more decisionmaking and productive roles, an economy can move faster and can accomplish (more assuredly) the state of sustainability in social, economic, and environmental dimensions.

Gender equality and women empowerment are fundamental to economic growth and development (WB and IMF, 2007; IMF, 2017). In the case of many developing countries, restraints like prejudiced laws, unfavorable traditions and social norms, inadequate legal protections, and inadequate access to financial and real assets have detained females back that in turn seized back economic growth (World Development Resources, 2012). Therefore, to attain sustainable economic growth in an entity there is a need to ensure gender equality that uplifts the path of economic development and growth. Gender equality not only assists in conquering sustainable economic growth but also contributes in multiple direct and indirect ways.

Likewise, females tend to invest more in the health and education of their families, develop an improved and better human capital to petrol the upcoming economic growth in an economy. Facilitating full and active females' participation in an economy not only promotes growth, but also expands economies, condenses inequality of income, and alleviates demographic modifications. According to the United Nations High-level Panel Report (2016) about Females' Economic Empowerment, there's a small number of females working in paid jobs as compared to men, furthermore, females' paid earnings are relatively lower than men's (UN, 2016). Therefore, there is a need to implement policies that can improve the labor market situation and construct a level field or ground of work for men and women (IMF, 2013).

Besides gender equality, consistent employment trends also significantly determine sustainable economic growth. Increased 
unemployment rate causes a decline, and decreased unemployment rate causes an increase in GDP or economic growth. Employment trends in an economy reflect or measures the economic stability of an economy. Economic stability facilitates attain sustainable economic growth that will construct a better environment for employment by providing healthy job activities. It also promises inevitability and assurance to investors that improves available human resource and their utilization. According to IMF (2016) statistics, economic stability averts financial and economic crises, economic activity fluctuations, unemployment, and inflation. Moreover, economic stability shields a nation from external shocks.

Conversely, unemployment exerts multi-dimensional influence on an entity such as economic, social, and political impacts. Unemployment upsurges economic and social disturbance causing delicate social cohesion increases crime rates deteriorate law \& order situation and decreasing living standards in an economy. Unemployment is a social and economic disgrace for both men's and women's labor force participation. Therefore, there is a need to stabilize the current prevailing trend in an economy, to secure the path of sustainable economic growth from any sort of hindrances and blocks.

\section{LITERATURE REVIEW}

Beneria (2001) deliberated the patterns of employment, jobs in formalization and gender equality. This research disclosed that during past decades jobs in formalization influenced the low \& high income economies that further leads to poverty and economic insecurity. In addition, this paper analyzed women's employment and participation in the informal sector. Results disclosed that some contradictory factors greatly influence women's employment. Social protection and re-distribution mechanism were the prime solutions to combat the preceding scenario.

Luci (2009) documented the affiliation amid labor market participation of women and economic growth. The focus of this study was on highlighting the effect of economic growth on gender inequality. The subsequent study selected developing economies for empirical examination, 184 developing countries had been examined over the period 1965-2005. System-GMM and pooled OLS estimation had been utilized for analysis. Statistical estimates of this study 
affirmed the presence of 'feminization $U$ ' in developing economies. Feminization-U reflected the conception that at the beginning or short run economic growth lowers female participation in the labor market but after that or in long run it increases women's participation.

Tchouassi (2012) hypothesized the role of gender equality in sustainable development for the economies of central Africa. In this paper eleven (11) countries of central Africa have been empirically examined throughout the year 2011. Empirical estimates concluded that there's a statistically significant association between multidimensional poverty index (MPI), Gini index, gender inequality index, and sustainable development index. Besides, by covering the gender gap a country can attain a state of sustainable development. In the case of developing countries gender equality ensures structural transformation. In sum, we can say that gender equality plays a significant role in the achievement of sustainable development.

Gaddis and Klasen (2014) documented the nexus of women's participation in the labor force, Structural Changes, and economic development by examining the U-shape feminization hypothesis for the German economy. This research has highlighted the dire need for harmonization and it also pursued quality control on overseas statistics of employment. Panel data from the period 1990-2011 had been chosen for analysis estimation. Estimates of regression analysis provoked that education, fertility dynamics and structural changes influenced feminization U-hypothesis and declining portion of Uhypothesis is crucial for developing economies. Moreover, at the global level (or platform) no strong and provoking regulations and laws exist, about females' labor force engagement.

Leong (2013) and Alao (2015) initialized that gender inequality and poor empowerment of women's retard betterment in living standards of women. Furthermore, gender inequality and poor empowerment of women's work are a clog in contributions to economic development and governance. The findings of these two papers concluded that gender equality enhances the chances for women to access education facilities, health facilities, access to microfinance credit and access towards other productive resources. On the other hand, gender inequality low-lifted the quality of life, results in declining or limited productivity and hinders the economic growth efficiency of an entity. 
Bertay, Dordevic and Sever (2018) examined the affiliation amid gender inequality and the growth of an economy. For estimation researcher selected industry level data for six countries that were Sweden, Canada, Austria, Ireland, Australia, New Zealand. Estimates provoked that for the case of more gender-equal economies, within female dominated industries growth is relatively faster as compared to the low gender-equal economies. Estimates were declared error and outliers free after examining robustness tests. The overall findings of this paper were that gender inequality caused a significant casual effect at the industry level, on real economic factors (or outcomes).

Mustafa (2020) deliberated the association amid empowerment of women and labor force participation of females for the economy of Bangladesh. The key objective of this paper is to address the problems caused by women's engagement in the informal sector. As from the preceding two decades, women's participation in the labor force has been increased but most of this uplifting are in the informal sector. Therefore, there's no qualitative improvement in the work manner or in empowering activity of women. This study pursued the informal sector reasonable for violation of labor market rules and laws, particularly for the case of women. Researchers suggested that there's a need to conduct steps that empower women and save the violation of their rights in the informal sector.

\section{DATA COLLECTION AND METHODOLOGY}

To check the affiliation of gender inequality with economic growth researcher utilized an econometric research model:

$G D P R_{t}=\beta_{0}+\beta_{1} G D P R_{t-1}-\beta_{2} G I I_{t}-\beta_{3} U N F M_{t}-\beta_{4} I N F_{t}+\beta_{5} L F E X P C_{t}+$ $\beta_{6} P O P T_{t}+\varepsilon_{t} \ldots \ldots E q(1)$

The second model of this study mainly elucidates the affiliation amid employment trends and GDP growth rate:

$G D P R_{t}=\beta_{0}+\beta_{1} G D P R_{t-1^{-}} \beta_{2} U N T O T_{t}-\beta_{3} I N Q_{t}-\beta_{4} I N F_{t}+\beta_{5} E D U I_{t}-$ $\beta_{6} P O P T_{t}+\varepsilon_{t} \ldots \ldots . . . E q(2)$

While, the third model of this study integrates the affiliation amid gender inequality, employment trends and sustainable economic growth:

$G D P R_{t}=\beta_{0}+\beta_{1} G D P R_{t-1^{-}} \beta_{2} G I I_{t}-\beta_{3} U N T O T_{t}-\beta_{4} U N F M_{t}-\beta_{5} I N Q_{t}-$ $\beta_{6} I N F_{t}+\beta_{7} L_{F E X P C_{t}}+\beta_{8} E D U I_{t}+\beta_{9} P O P T_{t}+\beta_{10} E M P P_{t}+$ $\varepsilon_{t} \ldots \ldots \ldots \ldots \ldots \ldots q(3)$ 


\section{DATA SOURCE}

The countries that are considered in this research for empirical estimation are Bangladesh, India, Pakistan and Iran (BIPI economies). There are multiple reasons for encompassing these four countries detailed in the introduction chapter. According to the list of IWA (international water association), low income countries in 2019, Bangladesh, India, Pakistan and Iran are low income countries of south Asia. This classification has been donned based on per capita income in the year 2020. According to IWA Countries that affirmed per capita income level lower than 12.056 dollars has been categorized as lowincome state. Not only IWA but also World Economic Situation and Prospects (WESP), 2014 disclosed that Bangladesh, India, Pakistan and Iran as low-income countries region wise. The time covered in this research is from 2011 to 20119.

For empirical estimation, real GDP (GDPR) Growth, Gender Inequality Index (GII), Unemployment (UNTOT), Unemployment female to male ratio (UNFM), Human Inequality Coefficient (INQ), Inflation (INF), Life expectancy at birth (LFEXPC), Education index(EDUI), Population (POPT) and Employment to population ratio (EMPP) are utilized as a research variable. GDPR is considered as a proxy measure for sustainable economic growth and utilized as a dependent variable in all (three) models of this research. For data collection of the examined variables of this study researcher utilized multiple reliable data sources. The data source of all variables is the United Nations development program (UNDP) report 2020, except for Real GDP and Inflation. The data source of Real GDP is World Economic Situation and perspective (WESP) 2020 report while the data for Inflation is collected from World Economic Outlook (WEO) 2020 report.

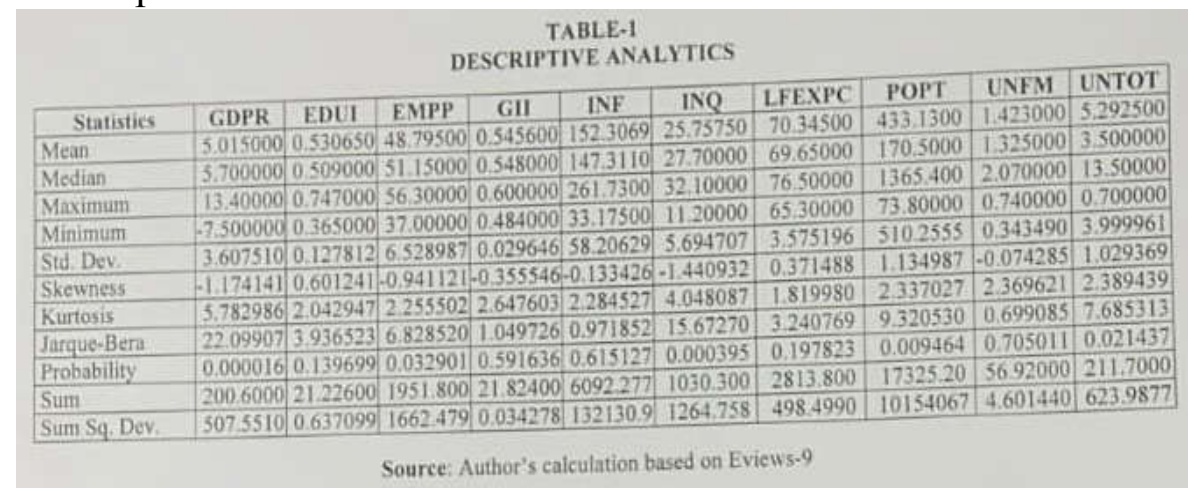


The table of descriptive statistics replicates the summary statistics of the examined data series. Mean and median values, displayed in this table, show the average tendency of the examined variables of the study. And the maximum and minimum values reflect the high and low values and range of data series. Estimates of standard deviation demonstrate the tendency or range of deviation from the actual estimates (how much data may deviate from its mean). Skewness and kurtosis are the measures of normal distribution (shape) or the degree of flatness and peakedness of the data series measured by these two tools. The probability value and Jarque-Bera value shows probability or chances of dispersion. At the end observation value shows the actual observation examined by this research is 40 .

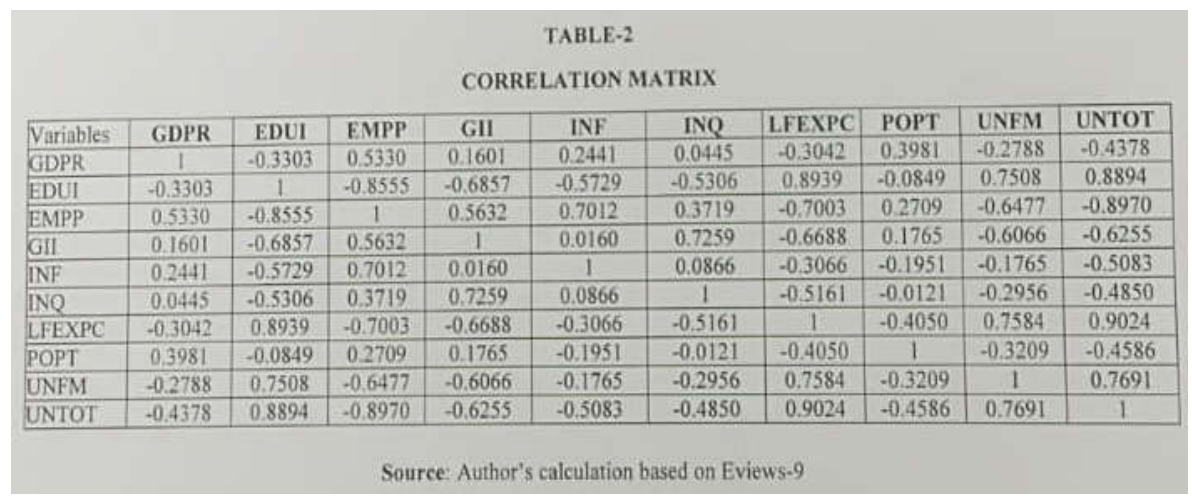

In the above-exhibited table, correlation of examined variables with each other is exhibited, via using correlation matrix, in Eviews. In correlation analysis, it is required that each variable correlation with itself must be one or diagonal because it shows that the variable has a perfect relationship or is exactly correlated with itself. For instance, GDPR has an exact correlation with itself so, its effect on itself is one. As the table demonstrates, the correlation of each variable with itself is equal to one. Furthermore, after checking diagonal value researcher must check the correlation of variables with others to detect multi-colinearity (high dependence of one independent variable with other variables) presence in the examined data series. 
Biannual Research Journal Grassroots Vol.55, No.II: 22-39

\begin{tabular}{|c|c|c|c|}
\hline \multicolumn{4}{|c|}{$\begin{array}{c}\text { TABLE-3 } \\
\text { GRANGER CAUSALITY }\end{array}$} \\
\hline Null Hypothesis: & Observation & F-Statistic & Probability \\
\hline EDUI does not Granger Cause GDPR & 32 & 1.27796 & 0.0249 \\
\hline \multicolumn{2}{|l|}{ GDPR does not Granger Cause EDUI } & 0.38675 & 0.6830 \\
\hline EMPP does not Granger Cause GDPR & 32 & 5.79389 & 0.0081 \\
\hline GII does not Granger Cause GDPR & 32 & 5.25181 & 0.0118 \\
\hline \multicolumn{2}{|l|}{ GDPR does not Granger Cause GII } & 1.15961 & 0.3287 \\
\hline INF does not Granger Cause GDPR & 32 & 3.05766 & 0.0635 \\
\hline UNTOT does not Granger Cause GDPR & 32 & 4.38740 & 0.0224 \\
\hline \multicolumn{2}{|l|}{ GDPR does not Granger Cause UNTOT } & 0.42245 & 0.6597 \\
\hline EMPP does not Granger Cause EDUI & 32 & 0.66977 & 0.5201 \\
\hline \multicolumn{2}{|l|}{ EDUI does not Granger Cause EMPP } & 0.20592 & 0.8152 \\
\hline GII does not Granger Cause EDUI & 32 & 1.50847 & 0.2393 \\
\hline \multicolumn{2}{|l|}{ EDUI does not Granger Cause GII } & 2.96128 & 0.0687 \\
\hline \multicolumn{2}{|l|}{ EDUI does not Granger Cause INQ } & 4.54482 & 0.0199 \\
\hline LFEXPC does not Granger Cause EDUI & 32 & 5.57889 & 0.0094 \\
\hline \multicolumn{2}{|l|}{ EDUI does not Granger Cause LFEXPC } & 0.60680 & 0.5524 \\
\hline POPT does not Granger Cause EDUI & 32 & 0.04800 & 0.9532 \\
\hline UNFM does not Granger Cause EDUI & 32 & 1.34309 & 0.2779 \\
\hline \multicolumn{2}{|l|}{ EDUI does not Granger Cause UNFM } & 3.12346 & 0.0602 \\
\hline UNTOT does not Granger Cause EDUI & 32 & \begin{tabular}{|l|}
0.58201 \\
\end{tabular} & 0.5656 \\
\hline \multicolumn{2}{|l|}{ EDUI does not Granger Cause UNTOT } & \begin{tabular}{|l|}
2.44679 \\
\end{tabular} & 0.1055 \\
\hline GII does not Granger Cause EMPP & 32 & 0.69053 & 0.5099 \\
\hline \multicolumn{2}{|l|}{ EMPP does not Granger Cause GII } & 0.74877 & 0.4825 \\
\hline INF does not Granger Cause EMPP & 32 & 3.60270 & 0.0410 \\
\hline \multicolumn{2}{|l|}{ EMPP does not Granger Cause INF } & 5.25216 & 0.0118 \\
\hline INQ does not Granger Cause EMPP & 32 & \begin{tabular}{|l|}
0.51932 \\
\end{tabular} & 0.6007 \\
\hline \multicolumn{2}{|l|}{ EMPP does not Granger Cause INQ } & 1.81084 & 0.1828 \\
\hline LFEXPC does not Granger Cause EMPP & 32 & 1.38417 & 0.2677 \\
\hline \multicolumn{2}{|l|}{ EMPP does not Granger Cause LFEXPC } & 0.06172 & 0.9403 \\
\hline POPT does not Granger Cause EMPP & 32 & 1.49078 & 0.2432 \\
\hline \multicolumn{2}{|l|}{ EMPP does not Granger Cause POPT } & 0.31141 & 0.7350 \\
\hline UNFM does not Granger Cause EMPP & 32 & 0.83917 & 0.4430 \\
\hline \multicolumn{2}{|l|}{ EMPP does not Granger Cause UNFM } & 1.51367 & 0.2382 \\
\hline UNTOT does not Granger Cause EMPP & 32 & 0.90335 & 0.4171 \\
\hline INF does not Granger Cause GII & 32 & 0.56688 & 0.5739 \\
\hline \multicolumn{2}{|l|}{ GII does not Granger Cause INF } & 10.3938 & 0.0004 \\
\hline
\end{tabular}


Biannual Research Journal Grassroots Vol.55, No.II: 22-39

\begin{tabular}{|c|c|c|c|}
\hline INQ does not Granger Cause GII & 32 & 1.25586 & 0.3009 \\
\hline \multicolumn{2}{|l|}{ GII does not Granger Cause INQ } & 5.91192 & 0.0074 \\
\hline \multicolumn{2}{|l|}{ GII does not Granger Cause LFEXPC } & 3.74707 & 0.0366 \\
\hline POPT does not Granger Cause GII & 32 & 1.52949 & 0.2348 \\
\hline \multicolumn{2}{|l|}{ GII does not Granger Cause POPT } & 1.15526 & 0.3301 \\
\hline UNFM does not Granger Cause GII & 32 & 1.58774 & 0.2229 \\
\hline \multicolumn{2}{|l|}{ GII does not Granger Cause UNFM } & 1.01901 & 0.3744 \\
\hline UNTOT does not Granger Cause GII & 32 & 0.03910 & 0.9617 \\
\hline \multicolumn{2}{|l|}{ GII does not Granger Cause UNTOT } & 0.37319 & 0.6920 \\
\hline INQ does not Granger Cause INF & 32 & 17.6475 & $1 . \mathrm{E}-05$ \\
\hline \multicolumn{2}{|l|}{ INF does not Granger Cause INQ } & 0.46636 & 0.6322 \\
\hline LFEXPC does not Granger Cause INF & 32 & 2.93240 & 0.0704 \\
\hline \multicolumn{2}{|l|}{ INF does not Granger Cause LFEXPC } & 0.86012 & 0.4344 \\
\hline POPT does not Granger Cause INF & 32 & 0.38091 & 0.6869 \\
\hline \multicolumn{2}{|l|}{ INF does not Granger Cause POPT } & 1.89553 & 0.1697 \\
\hline UNTOT does not Granger Cause INF & 32 & 4.37889 & 0.0225 \\
\hline \multicolumn{2}{|l|}{ INF does not Granger Cause UNTOT } & 0.87034 & 0.4302 \\
\hline LFEXPC does not Granger Cause INQ & 32 & 2.84611 & 0.0756 \\
\hline \multicolumn{2}{|l|}{ INQ does not Granger Cause LFEXPC } & 4.02653 & 0.0295 \\
\hline POPT does not Granger Cause INQ & 32 & 1.40201 & 0.2635 \\
\hline \multicolumn{2}{|l|}{ INQ does not Granger Cause POPT } & 0.84477 & 0.4407 \\
\hline UNFM does not Granger Cause INQ & 32 & 1.66727 & 0.2076 \\
\hline \multicolumn{2}{|l|}{ INQ does not Granger Cause UNFM } & 0.30102 & 0.7425 \\
\hline UNTOT does not Granger Cause INQ & 32 & 1.51927 & 0.2370 \\
\hline \multicolumn{2}{|l|}{ INQ does not Granger Cause UNTOT } & 1.27610 & 0.2954 \\
\hline POPT does not Granger Cause LFEXPC & 32 & 0.59647 & 0.5578 \\
\hline \multicolumn{2}{|l|}{ LFEXPC does not Granger Cause POPT } & 2.27909 & 0.1217 \\
\hline \multicolumn{2}{|l|}{ LFEXPC does not Granger Cause UNFM } & 0.72532 & 0.4934 \\
\hline UNTOT does not Granger Cause LFEXPC & 32 & 2.51537 & 0.0996 \\
\hline \multicolumn{2}{|l|}{ LFEXPC does not Granger Cause UNTOT } & 0.30640 & 0.7386 \\
\hline UNFM does not Granger Cause POPT & 32 & 1.58163 & 0.2241 \\
\hline \multicolumn{2}{|l|}{ POPT does not Granger Cause UNFM } & 0.90745 & 0.4155 \\
\hline UNTOT does not Granger Cause POPT & 32 & 0.23080 & 0.7955 \\
\hline \multicolumn{2}{|l|}{ POPT does not Granger Cause UNTOT } & 0.66987 & 0.5201 \\
\hline UNTOT does not Granger Cause UNFM & 32 & 4.45959 & 0.0212 \\
\hline \multicolumn{2}{|l|}{ UNFM does not Granger Cause UNTOT } & 0.26167 & 0.7717 \\
\hline
\end{tabular}

Source: Author's calculation based on Eviews-9 
Here, according to statistical estimation (for rejecting the null hypothesis), we need a probability value lower than 0.05 or 0.09 (that are critical values). Estimates of EDUI indicate that there is a granger causality between EDUI and GDPR. Here probability value is 0.02 which is lower than the critical value of 0.05 . Therefore, we can reject the null hypothesis and accept the alternative hypothesis which states that there is a cause and effect relationship between EDUI and GDPR. On the other hand, if we consider the cause and effect relationship between GDPR and EDUI, it shows that there is no statistically significant cause and effect relationship between GDPR and EDUI. Because the probability value is higher than the critical value of 0.05 which is 0.68. In the simplest term, EDUI cause or determine GDPR but GDPR does not cause or determine EDUI.

Estimates of EMPP indicate that there is a granger causality between EMPP and GDPR. On the other hand, if we consider the cause and effect relationship between GDPR and EMPP, it shows that there is no statistically significant cause and effect relationship between GDPR and EMPP. Because the probability value is higher than the critical value of 0.05 which is 0.90 . Estimates of GII indicate that there is a granger causality between GII and GDPR. However, there is no statistically significant cause and effect relationship between GDPR and GII. In simple words, GII cause or determine GDPR but GDPR does not cause or determine GII.

Estimates of INF indicate that we can reject the null hypothesis and accept the alternative hypothesis which states that there is a cause and effect relationship between INF and GDPR. Furthermore, if we consider the cause and effect relationship between GDPR and INF, it shows that there is a statistically significant cause and effect relationship between GDPR and INF. Estimates of INQ indicate that there is a granger causality between INQ and GDPR. On the other hand, if we consider the cause and effect relationship between GDPR and INQ, it shows that there is no statistically significant cause and effect relationship between GDPR and INQ.

Estimates of LFEXPC indicate that there is no Granger causality between LFEXPC and GDPR. Furthermore, if we consider the cause and effect relationship between the GDPR and LFEXPC, it shows that there is also no statistically significant cause and effect relationship between GDPR and LFEXPC. Estimates of POPT indicate that there is 
a granger causality between POPT and GDPR. But, if we consider the cause and effect relationship between GDPR and POPT, it shows that there is a statistically significant cause and effect relationship between GDPR and POPT.

Estimates of UNFM indicate that there is a granger causality between UNFM and GDPR. Besides, if we consider the cause and effect relationship between GDPR and UNFM, it shows that there is no statistically significant cause and effect relationship between GDPR and UNFM. Estimates of UNTOT indicate that there is a granger causality between UNTOT and GDPR. Although, if we consider the cause and effect relationship between GDPR and UNTOT, it shows that there is no statistically significant cause and effect relationship between GDPR and UNTOT.

The above discussed all cause and effect relation depicts causality relation of all independent variables with the dependent variable (GDPR). While In the remaining table causality groups, the granger cause and effect relationship of independent variables with each other is documented. Such as EMPP does not granger cause EDUI and EDUI does not granger cause EMPP. GII does not granger causes EDUI but EDUI granger cause GII. Meanwhile, INF does not granger cause EDUI but EDUI does granger cause INF. INQ does not granger cause EDUI but EDUI does granger cause INQ. LFEXPC does granger cause EDUI but EDUI does not granger cause LFEXPC. POPT does not granger cause EDUI and EDUI also do not granger cause POPT.

GMM Estimation: Generalized Method of Moment (GMM) is an estimation approach used for measuring long run association between the examined variables of this research, utilized by the researcher. The following table encompasses estimates of:

TABLE-4

GENERALIZED METHOD OF MOMENT (GMM)

\begin{tabular}{llll}
\hline Variables & Model-1 & Model-2 & Model-3 \\
\hline GDPR $_{\mathrm{t}-1}$ & 7.0515 & 8.6215 & 8.3414 \\
& {$[2.04]$} & {$[2.88]$} & {$[2.22]$} \\
GII & $(0.000)$ & $(0.000)$ & $(0.000)$ \\
& $-8.9612 *$ & ---- & $-2.5111^{*}$ \\
& {$[8.56]$} & ---- & {$[2.29]$} \\
& $(0.000)$ & ---- & $(0.075)$
\end{tabular}


Biannual Research Journal Grassroots Vol.55, No.II: 22-39

UNTOT

UNFM

INQ

INF

LFEXPC

EDUI

POPT

EMPP

Constant
$-1.7213^{*}$

$[-4.26]$

$(0.000)$

$-5.9813^{*}$

$[-6.54]$

$(0.000)$

$---$

$---$

$---$

$-1.1515^{*}$

[2.27]

$(0.031)$

2.6414*

[2.37]

(0.025)

$\begin{array}{ll}--- & 4.8912 * \\ --- & {[5.67]} \\ --- & (0.000)\end{array}$

1.5016

[2.53]

(0.017)

$-$

$--$

$--$

$2.8812 *$

[2.37]

(0.025)
$-8.1816^{*}$

[-5.72]

(0.000)

$---$

$-$

$---$

$-1.3612 *$

[-4.67]

(0.075)

0.982

0.833

0.292

0.165

[4.33]

[5.56]
$-4.3612^{*}$

[-2.35]

(0.027)

$-1.3111^{*}$

[2.03]

(0.054)

$-9.7714$

[-0.29]

2.3114

[0.40]

(0.696)

$1.5811^{*}$

[6.18]

(0.000)

4.8510*

[5.16]

(0.000)

3.7514*

(0.000)

5.7912*

[-4.82]

(0.000)

$-5.6310^{*}$

(0.000) 
Biannual Research Journal Grassroots Vol.55, No.II: 22-39

\begin{tabular}{llll}
\hline Sargon overid restrictions test & 0.000 & 0.000 & 0.000 \\
Sargon excluding group test & 1.000 & 1.000 & 0.000 \\
J-statistics & 27.45320 & 28.32670 & 30.00000 \\
No. of years & 10 & 10 & 10 \\
No. of Countries & 4 & 4 & 4 \\
No. of Instruments & 36 & 36 & 36 \\
\hline
\end{tabular}

Source: Author's calculation based on Stata-14

Note: Coefficient value with starrer $(*)$ indicates $1 \%$ significant level, value in parenthesis [] is t-static, value in parenthesis () is p-value.

The generalized method of moment (GMM) is an estimation approach mostly utilized for panel data estimation when endogeneity exists in data series. GMM provides the most consistent and better results than that other estimation approaches such as regression, mixed and random effect, and Co-integration approaches. To explicate affiliation of gender inequality, sustainable economic growth, and employment trends above displayed table have been divided into the form of three models. The focus of the first model is on gender inequality and sustainable economic growth relationship. While the second model explicate employment trends influence on sustainable economic growth and the third model is a combination of first two models that combines variables of prior two model and illustrates the association amid gender inequality, employment trends and sustainable economic growth.

Model-1, explicates that how gender inequality hinders or raises difficulties in the path of sustainable economic growth. Overall results confirm that there is statistically significant co-integration among the examined variables of this model. Furthermore, as because of gender inequality there is a statically significant decline in the sustainable economic growth rate. As because of gender inequality there is a "8.9612" percent change in economic growth. The reason behind this negative affiliation is that when gender inequality prevails in an economy it causes underutilization or exploitation of a massive amount of resources (human resources) such as the labor force.

Most females in an economy account for more than half of the total population share. But if in such an economy, females face inequality (in the form of available education, health, employment opportunities) or being discriminated it will cause a static influence on 
economic growth. Because if females got fewer employment opportunities then the economy loses its potential labor force that causes a reduction in the total output produced by an economy. On the other hand, if in an economy gender equality prevails it will assist the economy in achieving sustainable economic growth (Leong, 2013; Kazandjian, et.al. 2019; Asongu and Odhiambo, 2019).

UNFM causes a "-5.9813" percent decline in GDP growth. Increased females unemployment causes a reduction in economic growth in the sense that the available potential labor force is not utilized in an optimized manner that results in low production than the possible one. Therefore, increased females employment opportunities are needed for optimal allocation of resources and increased production of an economy (Shabbir and Zeb, 2018; Kazandjian, et.al. 2019; Asongu and Odhiambo, 2019). Inflation causes a "1.1515" percent decline in the economic growth of BIPI economies.

High goods prices discourage consumption that in turn reduces investment level, the decline in investment level will cause low labor force enforcement that negatively influences economic growth (Shabbir and Zeb, 2018). As because of life expectancy (LFEXPC), GDP changes by "2.6414". Increased life expectancy (LFEXPC) reflects the availability of better health facilities. Furthermore, increased life expectancy or better health facilities provokes increased productivity that in turn provokes the high or increased GDP growth of an economy (Leong, 2013; Alao 2015; Kazandjian, 2019). Estimates for Population (POPT) reflects that because of increased population, GDP growth rate changes by "1.5016". Increased labor surplus provokes increase human capital (Bertay, et.al. 2018; Tsani, et.al. 2013).

Model-2, explicates that how employment trends prevailing in an economy can influence or can raise difficulties for sustainable economic growth. Overall results confirm that there is statistically significant co-integration among the examined variables of this model. Furthermore, unemployment (UNTOT) causes a decline in sustainable economic growth. As unemployment increases in an economy, it reflects low labor recruitment in the labor force. This results in the form of low or declining household income and per-capita income. As because of the reduced income of households, the overall consumption and investment level of that economy decreases. 
And because of this declining investment rate unemployment rate increases again. The overall impact of this prevailing unemployment rate in the marketplace is that it reduces the real GDP growth rate by reducing the goods and services production level (Tsani et.al., 2013; Lechman and Kaur, 2015). The human inequality coefficient (INQ) will result in a "-4.3514" percent decline in the real GDP rate. Besides, Inflation causes a "-4.4015" percent decline in economic growth. Estimating the value of the education index (EDUI) aggravated that there is a "4.8912" percent increase in real GDP growth rate.

Increased education rate or large value of education index (EDUI) in an economy shows that a large number of labor or human capital in that economy is educated and skilled. Skilled labor utilizes economic resources significantly and causes an increases growth rate of GDP (Klasen and Pieters, 2012; Leong, 2013; Chattopadhyay, 2018). Estimated Population (POPT) value replicates that because of increased population in BIPI economies, rate GDP growth rate changes by "8.1816". Bertay, et.al., (2018); Tsani, et.al., (2013) signified that population significantly determines the economic growth of an economy.

Model-3 elucidates the association amid gender inequality, employment trends and sustainable economic growth. This model also testifies the classical model, which states that adding (or factoring) more variables in any gender specified models (gender inequality models), for reducing the portion of unexplained prevailing residual just reduces residuals but does not rule out gender specified inequality or gap. So, for testing this theory more variables are introduced to the gender inequality (first model) model. And the result of this model affirmed that adding more variable not only reduces residual portion but also lower down (as compared to the first model) the influence of gender inequality on economic growth.

Gender inequality index (GII) causes "-2.5111" percent change in BIPI economy's growth. Here, the low value of GII validates the classical theory. Leong (2013); Kazandjian, et.al. (2019); Asongu and Odhiambo (2019) provoked that as because of gender inequality there's a decline and because of gender equality there's an increase in the economic growth of an economy. Furthermore, there's a need to introduce policies that can raise active females participation in the 
labor force. Increased females employment opportunities are needed for optimal allocation of resources and increased production of an economy.

As because of UNFM there is a significant decline in the real GDP growth rate (Shabbir and Zeb, 2018; Kazandjian, et.al., 2019; Asongu and Odhiambo, 2019). Estimates of the unemployment rate are statistically significant. Estimating the value of unemployment affirmed that because of unemployment (UNTOT) there is a "-4.3612" percent decline in GDP. Tsani, et.al., (2013); Lechman and Kaur (2015) emphasized that unemployment negatively influences with economic growth of an economy. Unemployment causes a decline in GDP while, on the other hand, employment significantly increases the GDP growth rate.

The human inequality coefficient (INQ) will result in a "-9.7714" percent decline in the real GDP rate. The reason behind this negative association is that inequality replicates unequal distribution of resources or unspecified resource allocation. It also shows that a group of masses is enjoying massive benefits while the other one is deprived even of basic rights. Therefore, for accomplishing a stable and steady path of sustainable economic growth an economy requires equality or a low index value of the Human inequality coefficient.

As because of life expectancy (LFEXPC), GDP changes by "1.5811". Increased life expectancy (LFEXPC) reflects the availability of better health facilities. Furthermore, increased life expectancy or better health facilities provokes increased productivity that in turn provokes the high or increased GDP growth of an economy (Leong, 2013; Alao, 2015; Kazandjian, 2019). Estimating the value of the education index (EDUI) aggravated that there is a " 4.8510 " percent increase in real GDP growth rate. Klasen and Pieters (2012); Leong (2013); Chattopadhyay (2018) in their researches intensified the importance of education for the economic growth of an economy.

Estimated Population (POPT) value replicates that GDP growth rate changes by "-3.7514". As if in an economy population increases then it means that now that economy has more labor available for production activities. Increased labor surplus provokes increase human capital. Optimal and proper utilization of increased labor surplus can lead an economy towards sustainable economic growth of an economy. But if proper employment opportunities are not raised, it 
converts this positive association into a negative one as happened in this model (Bertay, et.al. 2018; Tsani, et.al., 2013).

Results for employment to population ratio (EMPP) demonstrates that GDP changes by "5.7912". Estimates of AR (1) and AR (2) clarifies that there is no serial correlation in this model. Value of Sargon over-identifying test shows that model is consistent and stable. Besides this estimates for Sargon excluding test provoked that model is statistically significant and consistent.

\section{CONCLUSION}

Gender inequality, unemployment, and some other macroeconomic, social, demographic and financial factors are incorporated over 2011 to 2020. This research considers three different statistical models. For statistical estimation of long run affiliation granger causality and Generalized Method of Moment (GMM) is utilized by the researcher. Gender inequality negatively influences sustainable economic growth. Employment trends also contribute to influencing economic growth. Moreover, there is a statistically significant association amid gender inequality, employment trends and sustainable economic growth. Furthermore, factoring more variables in gender specified model does not rule out gender inequality. Approximation and Results of this research are economically, socially and statistically significant, and these estimations are unlikely to be driven out by the outliers, any measurement errors, omitted variable bias, and reverse causality between variables. Overall Findings suggest that gender equality and stable employment trends are the key drivers of sustainable economic growth.

\section{REFERENCE}

Alao, E. M. (2015). Inequality, poverty among Nigeria women and youth and the challenges of inclusive growth in post 2015 millennium development goals (MDG). International Journal of Development and Economic Sustainability, 3(5), 15-25.

Asongu, S., \& Odhiambo, N. (2020). Inequality Thresholds, Governance and Gender Economic Inclusion in sub-Saharan Africa. Forthcoming, International Review of Applied Economics.

Beneria, L. (2001). Changing employment patterns and the formalization of jobs: general trends and gender dimensions. Geneva: International Labour Organization.

Bertay, A., Dordevic, L., \& Sever, C. (2018). Gender Inequality and Economic Growth: Evidence from Industry-Level Data. 
Chattopadhyay, A. (2018). A study on the status of higher education of women and economic empowerment in India. Research Journal of Social Sciences, 9(7).

Donald, K., \&Lusiani, N. (2017). The IMF, Gender Equality and Expenditure Policy. Bretton Woods Project.

Gaddis, I., \& Klasen, S. (2014). Economic development, structural change, and women's labor force participation. Journal of Population Economics, 27(3):639-681.

https://https-en-m-wikipedia-org.0.freebasics.com/wiki/Sustainability

International Labour Organization. (2018). World Employment and Social Outlook: Trends 2018. Geneva, Switzerland: Author

Kazandjian, R., Kolovich, L., Kochhar, K., \& Newiak, M. (2019). Gender equality and economic diversification. Social Sciences, 8(4):118.

Lechman, E., \& Kaur, H. (2015). Economic growth and female labor force participation-verifying the U-feminization hypothesis. New evidence for 162 countries over the period 1990-2012. New evidence for, 162, 19902012.

Leong, S. (2013). Women's business, 1edn. Accessed 12 June 2018 from Sandy Leong \& Book boon.com. Makama, G. A. (2013). Patriarchy and gender inequality in Nigeria: The way forward. European Scientific Journal, 9(17):115-144.

Luci, A. (2009). Female labor market participation and economic growth. International Journal of Innovation and Sustainable Development, 4(2/3):97-108.

Mustafa, A. (2020). An analysis of the nexus between female labor force participation and women's empowerment in Bangladesh (Doctoral dissertation, Brac University).

Shabbir, M. S., \& Zeb, A. (n.d.). Determinant of Economic Stability through Female Unemployment: Evidence from Pakistan.

Tchouassi, G. (2012). Does Gender Equality work for Sustainable Development in Central Africa Countries? Some Empirical Lessons. European Journal of Sustainable Development, 1(3):383-398.

Tsani, S., Paroussos, L., Fragiadakis, C., Charalambidis, I., \& Capros, P. (2013). Female labor force participation and economic growth in the South Mediterranean countries. Economics Letters, 120(2):323-328.

Undp., \& UNDP. (2008). Human Development Report 2007/2008. UN.

Undp., \& UNDP. (2016). Human Development Report 2016/2017. UN.

Unicef, D. P. R. (2019). Annual Report 2012. Unicef.

World Bank. (2007). The World Bank Annual Report 2012. The World Bank.

World Bank. Available at www.worldbank.org/gender. 